\title{
THE OPTIMISM EXPRESSION FOR MIDDLE SCHOOL AGE STUDENTS IN PHYSICAL EDUCATION CLASSES
}

\author{
Romualdas Malinauskas, Artūras Akelaitis \\ Lithuanian Sports University, Kaunas, Lithuania
}

\begin{abstract}
Background. The paper strives to answer the question what is optimism expression for middle school age students in physical education classes. The following hypothesis was tested: optimism expression of boys would be higher than those of girls. The aim of our study was to examine the optimism expression for middle school age students in physical education classes.

Methods. The independent random sample consisted of 214 students of middle school age (108 girls and 106 boys). According to the attendance of physical education classes respondents by were divided into two groups: those who did not attend physical education classes for one month or more were assigned to the group of students not attending physical education classes, and others - the group of students attending physical education classes. The measure of optimism expression was evaluated using Dember's Optimism/Pessimism Scale.

Results. The hypothesis that optimism expression of boys would be higher than that of girls was confirmed. The comparison of optimism expression between boys and girls revealed that optimism expression for boys of middle school age was higher $(p<.05)$ than that of girls. The comparison of optimism expression among students attending and not attending physical education classes revealed that middle school age students (boys, girls) attending physical education classes were more optimistic $(p<.05)$.

Conclusions. It was found that the optimism of middle school age boys was higher in physical education classes comparing them to girls of the same age, and middle school age students (boys and girls) who attended physical education classes were more optimistic.
\end{abstract}

Keywords: physical education classes, the optimism expression, middle school age.

\section{INTRODUCTION}

$\mathrm{S}$ cientific studies carried out over the past decade on the behaviour, lifestyle and health of students in Lithuania have shown that mental health of school age children has a tendency to become worse in recent years (Petrauskiene \& Matulevičiūte, 2007). Comparing the indicators of Lithuania and other European countries, it was observed that mental health condition of Lithuanian students was unsatisfactory. Our country's children and teenagers are diagnosed with a lot of mental health disorder symptoms: the feeling of loneliness, stress, depression and suicidal thoughts. Lithuania is listed among countries where students do not feel safe at schools and are not happy when thinking about their current life. The suicide risk indicators of youth in Lithuania are very high and are still increasing, therefore this problem must be solved immediately and comprehensively (Zaborskis, 2001).

Physical activity positively affects mental health. Regular physical activities decrease cases of household and professional problems, as well as stress. Everyday problems can be managed more calmly when a person is in a good physical condition and is feeling great. Physical activity can be an excellent measure for temporarily relief 
of stress, improvement of the feeling of wellbeing making task planning easier and preventing the spread of fear and depression. Physical activity is a good distraction from everyday problems, and this helps overcome stressors (Poderys, 2000).

Studies confirm (Masiulis, 2006; Treben, 2006) that physical activity has a positive effect on emotions. Even a ten minute walk evokes optimism, the feeling of happiness, makes personal problems easier to solve and improves physical wellbeing (Thayer, 1987).

Optimism is a tendency to notice the positive sides of life and to positively assess reality (Keinys, 2003). In this article optimism is equated to positive self-esteem, positive emotions and lack of emotional problems.

Optimism provides self-confidence, strength and determines a positive attitude towards the environment, one's problems and the future (Chang \& Sanna, 2001). Optimists have more control over various situations, they are able to deal with stressful events more easily, and they are healthier and generally in a better mood (Scheier \& Carver, 1992). They achieve better results at work, in the academic field and in sports. They are more popular and often enjoy good relationships with other people (Peterson \& Steen, 2005).

Middle school age (adolescence) student group is unique. It is characterized by social, psychological and physiological development of personality activity (Barkauskaite, 2000). That is why this age span requires careful research in the context of physical education classes.

Goldberg and Chandler (1995) believe that various physical education programmes intended to fully educate middle school age children during physical education classes should aim to: a) create an atmosphere that would encourage positive emotions, so that students would know that they are evaluated depending on their improvement; b) help set realistic physical activity, learning and professional goals, as well as be aware of the importance of other roles regarding the future career; c) emphasize the improvement of skills as an achievement; d) develop emotional balance and restraint without arguing with other students; e) promote respect for one another.

Physical education philosophers and teachers often encourage middle school age students to rely on the principles and ideals of the Olympic Movement. According to Stoliarov (Столяров, 1998), Olympic education aims to familiarize children and youth with the Olympic ideals that focus on compassionate and humanistic sportrelated values that support the spirit of optimism. They are used to try to influence the knowledge system and form positive attitudes towards physical education classes. Šukys (2001) notes that the spiritual education of an athlete depends both on the values of the activity itself, as well as on the communication between the learner and the authoritative figures out of which physical education teachers receive the most important role. Therefore, interpersonal relations are of great importance. Good results can only be ensured by balanced mutual activities between the learner and the educator, i.e., communication that is based on acceptance and mutual respect, mutual sincerity and openness, as well as the promotion of an optimistic attitude (Šukys, 2001).

It is pointed out (Himberg, Hutchinson, \& Roussell, 2003) that physical education based on a narrow perspective aims to only develop the physical features, but when education is based on a broader perspective, the aim of physical education is to achieve greater results. Physical education teachers should be pedagogically prepared to develop an optimistic attitude of students toward the environment, especially of students who are between 12-18 years of age when their intellectual development is open to pedagogical intervention in physical education classes (Ostasevičienè, 2001).

Literature indicates that students also have certain feelings of low self-esteem (Pivorienè \& Jurkonyte, 2008). The awareness of personal imperfections forces to move forward, promotes growth and improvement. Problems start to arise when low self-esteem is very strong and a student starts to evaluate himself/herself pessimistically or thinks that he/she is worthless. In this case the student searches for ways to adapt or compensate his/her condition. Low self-esteem when there is a lack of optimism can be twofold: the student is passive, shy, reserved and distant or on the contrary - he/she is aggressive, arrogant and even cynical. Such student tends to humiliate and abuse others (Pivorienè \& Jurkonyte, 2008).

Optimism and positive personal self-esteem are like a social vaccine that builds an immune system to help overcome violence, bullying and inability to learn (Bulotaite, 1995). Since positive perception of self-esteem regulates the behaviour of an individual in various areas of life, strongly affects his/her interpersonal relationships, activity 
aims, direction selection, its effectiveness and determination in crisis situations, then it can be assumed that student's further development will depend on an optimistic attitude towards oneself during physical education classes (Malinauskas \&Klizas, 2009). How teachers evaluate children can be best presented by statistics. According to studies carried out in the US, the emotional relationship with oneself and one's life is positive for over 80 percent of kindergarten students (typical optimism), however, this number decreases down to 5 percent in the 12th grade (Bulotaite, 1995).

Cognitive abilities that increase during the middle school age period enable the student to understand and evaluate the significance of change and to think about future events, they encourage thinking about one's career, life and other important choices. The perception of one's own competence of these children depends on the feeling of their self-esteem; therefore it is important to maintain a positive optimistic attitude in physical education classes. It is believed (Weiss \& Amorose, 2005) that teenagers whose perceived competence is good in most areas are optimistic and have a positive selfworth, it is easier for them to accept the challenges of life, the learning process becomes interesting to them and they are not afraid to face difficulties.

When analysing the relation between general self-esteem and the perception of personal competence in various areas (academics, sports, social acceptance, physical appearance), it is stated that self-perception and esteem tend to increasingly change during the middle school age period: the perception of personal competence in various areas is at its lowest during early adolescence, and it starts to become adequate only during late adolescence. According to Navaitis (2001), due to variations in maturity and self-comparison with peers or icons which is typical of teenagers, it is hard for them to eavluate themselves adequately. Excessively good or poor self-esteem may be the incentive of aggressive or depressive behaviour and may lead to neurotic reactions.

The self-esteem amplitude of students in physical education classes is very wide. It fluctuates from side to side. It was observed that persons with similar abilities and achievements often evaluated themselves differently. Some tended to notably emphasize even their smallest achievements, they flaunted themselves and wanted their achievements to be mentioned as often as possible. While others acted completely differently - they did not feel proud of their achievements nor like it when people talked about them. There were also those who were talented and gifted, but appeared to be very unhappy with themselves, constantly blamed and condemned themselves even for the slightest mistakes or failures, considered themselves losers, felt distressed and tormented (Žemaitis, 1995). Thus, we can say that there is a certain esteem scale with two extremes: self-over-esteem (when a person is overly optimistic, has too much selfconfidence and overestimates his possibilities) and self-under-esteem (when a person is pessimistic and has no self-confidence). Positive self-esteem can be distinguished among these extremes. A student who tends to overestimate himself/herself often undermines others, views them as objects or means to reach his/her own objectives, and often initiates conflicts with people when they try to evaluate him/her objectively and treat him/her accordingly. During physical education classes, these students see themselves as much better than others, they think that they are stronger and more intellectual.

Low self-esteem in physical education classes creates not only a pessimistic mood, but also establishes a very negative relationship with oneself which can be called self-contempt. Self-contempt is expressed through self-hatred, condemnation, humiliation and disdain (Žemaitis, 1995). After discussing these extremes, a conclusion can be made that middle school age students estimating themselves in both of these cases do not know themselves very well. When a student reaches "balanced" self-esteem, it becomes easier for him/her to overcome difficulties, avoid unnecessary disappointments or negative emotions during physical education classes. Such a person is satisfied with the fact that he/she is the way he/ she is. He/she is an optimist, self-confident and is doing well. He/she is not plagued by jealousy or the feeling of insecurity; he/she does not have the loser complex. Such a person feels his/her own self-esteem (Kendall, 2001).

It is necessary to emphasized that positive selfesteem and optimism during physical education classes have a particularly significant value to a person's moral development, the development of his/ her spiritual world, self-confidence, self-criticism, modesty, self-esteem and the development of other important moral traits. Positive self-esteem is one of the most important goals of education, as it has an effect on the motivation of students in 
physical education classes and on the quality of task performance. Self-esteem, optimism and selfconfidence, - all these terms are used by physical education teachers who want to help their students form a better opinion about themselves. Additional student physical education development in schools could also help form positive self-esteem (Blauzdys \& Šinkūnienė, 2005). For example, a person's selfesteem in the area of physical education can be very low, however, if this area is not important to him/ her, it will have no negative effect on his/her selfesteem. Self-esteem depends not only on a person's skills in the area, but also on his/her belief on how others evaluate him/her (Horn, 2004). Therefore, if a student experiences success and believes that others acknowledge his/her competence, this can have a positive effect on his/her self-esteem and evoke optimism.

Perceived competence or perceived skills during physical education classes are not as consistent as self-esteem, since they can change over time depending on the person's achievements (Horn, 2004). At the beginning of the school year, a student may fully realize his/her physical competence, however he/she may have less success during physical education classes in secondary school compared to primary school.

Positive self-esteem and optimism are often analysed with the help of questionnaires. Research subjects must evaluate themselves on a five-point scale, by comparing with other research subjects of the same gender and age. Answers are marked. The result is determined by counting all the marked points (Auweelle, Bakker, Biddle, Durand \& Seiler, 1999). It is specified that self-esteem during the middle school age period is especially low. The selfesteem curve takes the form of the letter U (Marsh, 1989). Self-esteem and optimism start to decrease during the middle school age period, but they start to once again increase during late adolescence and cease to increase or decrease during youth. This tendency is characteristic of both genders. Sudden decrease in self-esteem begins from the age of $7-8$ years and continues until about 11 . Changes in self-esteem start to appear at the beginning of puberty, when the ability to more adequately evaluate oneself increases (Marsh, 1989). Selfesteem level decreases during early puberty. Selfesteem and perception of personal competence start to increase from around 13-14 years of age (Lintunen, Leskinen, Oinonen, Salinto, \& Rahkila,
1995), and physical education teachers should pay attention to this.

Researchers point out that it is necessary to strengthen optimism and positive self-esteem, as this is the guarantee of good mental health (Auweelle et al., 1999). It is stated that sometimes even illusory positive self-esteem is better than negative self-esteem. Optimism and positive illusions can be beneficial to middle school age students who often receive negative feedback in physical education classes (Lintunen et al., 1995). In this case, positive self-esteem does not mean that the image of oneself is distorted (Rosenberg, 1985). A realistic opinion of oneself appears during youth. It is a good thing when schools emphasize a realistic opinion of oneself as an educational goal. Of course, optimism and positive self-esteem show a person's psychological maturity.

Middle school age students start to realize their abilities, interests and goals, and this happens both consciously as well as subconsciously. Personal and social processes enable for the basic needs to develop during this age period, including the need for physical activity. These processes determine the development of the motivation structure and the personal needs of middle school age students, including the most important ones: self-confidence and anxiety control, optimism and positive selfesteem needs.

In the personal motivation structure of a middle school age student, satisfaction with physical activity is related to the teenager's newly achieved ideal self-image directed towards the realisation of physical activities in physical education classes, as well as the objectives of social identity. The emergence of this need changes the behaviour of students in this age group and increases their optimism and competence in activities that interest them (Немов, 2001). The pursuit of a goal encouraged by the need to be satisfied with one's life lies in real changes of personality and behaviour that comply with the development of abilities.

The need for optimism, self-confidence, positive self-esteem and anxiety control is related to a person's self-actualization (Palujanskienè, 2003). This personal need broadens the individualization and socialization processes of middle school age students. The development of self-confidence, anxiety control and optimism of middle school age students during physical education classes is of motivational nature. Optimism, positive self-esteem, ideal self-image and inner motivation activate the 
need for self-confidence and anxiety control. The inner motivation of the perception of personal self encourages active physical activity and becomes the most significant, due to the fact that when a person has strong inner motivation, it is easier for him/her to preserve self-esteem and the ability to adapt which strengthen self-confidence and anxiety control (Palujanskienè, 2003; Милякова, 2006). This means that the realisation of the need of self-confidence and anxiety control during physical education classes is not possible without positive self-esteem and optimism. Thus it can be stated that self-confidence and anxiety control, positive self-esteem and optimism during physical education classes are the foundation of the personal needs structure of a middle school age student.

Today, international scientific publications still lack data on optimism expression among middle school age students (boys and girls) in physical education classes. Data regarding such studies in Lithuania could not be obtained; therefore the relevance of the research on optimism expression among middle school age students in physical education classes is beyond doubt.

Research problem - what kind of optimism expression is among middle school age students (boys and girls) in physical education classes.

Research aim was to reveal the optimism expression for middle school age students (boys and girls) in physical education classes.

\section{METHODS}

Research participants. Research subjects were selected randomly. The research included middle school age (14-15 years old) students from Kaunas "Tadas Ivanauskas" secondary school, "S. Darius and S. Girènas" gymnasium and Kaunas
District Garliava Jonučiai progymnasium. The research sample consisted of 214 students from general education schools who were in the 8-9th grades (108 girls and 106 boys). The respondents were split into two groups according to their attendance of physical education classes: those who did not attend classes for a month or longer were categorized under the group of students who did not attend classes, while others were categorized under the group of students who attend physical education classes. Permission No. SMTEK-04 to carry out the research was granted by the Research Ethics Committee of the Lithuanian Sports University.

Measures. Dember, Martin, Hummer, Howe \& Melton's (1989) questionnaire was applied in order to evaluate optimism. Research subjects were provided with 56 statements that were rated on a 4-point Likert scale. Later, all the evaluations were summed and the final optimism indicator was obtained. Scale reliability was sufficient: optimism Cronbach's alpha was 0.79 .

Statistical analysis. In order to check the statistical hypotheses (for difference reliability among middle school age girls and boys), a Student's $t$ criterion was applied. The results were considered statistically significant if $p<.05$.

\section{RESULTS}

Using the Student's $t$ criterion, we have analysed the reliability of optimism differences for middle school age girls and boys in physical education classes. A statistically significant difference was found among students - boys and girls - who attended and did not attend physical education classes: middle school age students who attended physical education classes were more optimistic $(p<.05)$ (Table 1).

\begin{tabular}{|c|c|c|c|c|c|c|}
\hline \multirow{6}{*}{$\begin{array}{l}\text { Table } 1 \text {. The statistical indicators } \\
\text { of the optimism expression among } \\
\text { boys and girls attending and not } \\
\text { attending physical education } \\
\text { classes }(M \pm S D)\end{array}$} & Gender & \multirow[t]{2}{*}{ Variable } & \multirow{2}{*}{$\begin{array}{c}\begin{array}{c}\text { Attending } \\
\text { physical } \\
\text { education classes }\end{array} \\
n=72 \\
\end{array}$} & \multirow{2}{*}{$\begin{array}{c}\begin{array}{c}\text { Not attending } \\
\text { physical education } \\
\text { classes }\end{array} \\
n=34 \\
\end{array}$} & \multirow{2}{*}{$\begin{array}{c}\text { Scores of } \\
\text { Student's } \\
t \text {-test }\end{array}$} & \multirow[t]{2}{*}{$p$} \\
\hline & \multirow{3}{*}{ Boys } & & & & & \\
\hline & & $\begin{array}{l}\text { Optimism } \\
(M \pm S D)\end{array}$ & $50.86 \pm 6.07$ & $48.24 \pm 6.12$ & -2.06 & $p<.05$ \\
\hline & & $\begin{array}{c}\text { Pessimism } \\
(M \pm S D)\end{array}$ & $43.82 \pm 5.98$ & $42.85 \pm 6.67$ & -0.72 & $p>.05$ \\
\hline & \multirow{3}{*}{ Girls } & & $n=66$ & $n=42$ & & \\
\hline & & $\begin{array}{l}\text { Optimism } \\
(M \pm S D)\end{array}$ & $49.23 \pm 5.98$ & $46.76 \pm 6.01$ & -2.16 & $p<.05$ \\
\hline $\begin{array}{l}\text { Note. }(M \pm S D)-\text { mean and } \\
\text { standard deviation. }\end{array}$ & & $\begin{array}{c}\text { Pessimism } \\
(M \pm S D)\end{array}$ & $44.26 \pm 6.22$ & $43.08 \pm 6.17$ & -0.98 & $p>.05$ \\
\hline
\end{tabular}




\begin{tabular}{|c|c|c|c|c|}
\hline \multirow{2}{*}{ Variable } & $\begin{array}{c}\text { Attending } \\
\text { physical } \\
\text { education classes }\end{array}$ & $\begin{array}{c}\text { Not attending } \\
\text { physical } \\
\text { education classes }\end{array}$ & $\begin{array}{c}\text { Scores of } \\
\text { Student's } \\
\boldsymbol{n} \text {-test }\end{array}$ & $\boldsymbol{p}$ \\
\cline { 2 - 4 } & $\boldsymbol{n}=\mathbf{1 3 8}$ & $\boldsymbol{n}=\mathbf{7 6}$ & -2.11 & $p<.05$ \\
\hline $\begin{array}{c}\text { Optimism } \\
(M \pm S D)\end{array}$ & $50.03 \pm 6.17$ & $47.52 \pm 6.06$ & -0.94 & $p>.05$ \\
\hline $\begin{array}{c}\text { Pessimism } \\
(M \pm S D)\end{array}$ & $43.82 \pm 5.84$ & $42.96 \pm 6.09$ & -0.94 \\
\hline
\end{tabular}

\begin{tabular}{|c|c|c|c|c|}
\hline \multirow{2}{*}{ Variable } & Boys & Girls & \multirow{2}{*}{$\begin{array}{c}\text { Scores of } \\
\text { Student's } \\
\boldsymbol{t} \text {-test }\end{array}$} & $\boldsymbol{p}$ \\
\cline { 2 - 5 } & $\boldsymbol{n}=\mathbf{1 0 6}$ & $\boldsymbol{n}=\mathbf{1 0 8}$ & 1.96 & $p<.05$ \\
\hline $\begin{array}{c}\text { Optimism } \\
(M \pm S D)\end{array}$ & $49.58 \pm 6.01$ & $47.97 \pm 5.98$ & -0.39 & $p>.05$ \\
\hline $\begin{array}{c}\text { Pessimism } \\
(M \pm S D)\end{array}$ & $43.34 \pm 6.33$ & $43.67 \pm 6.20$ & -05 \\
\hline
\end{tabular}

Table 2. The statistical indicators of the optimism expression among students attending and not attending physical education classes $(M \pm S D)$

Note. $(M \pm S D)$ - mean and standard deviation.

Table 3. The statistical indicators of the optimism expression among boys and girls in physical education classes $(M \pm S D)$

Note. $(M \pm S D)$ - mean and standard deviation
After combining the data of both boys and girls during the analysis, it was found that the optimism of middle school age students who attended physical education classes was expressed more clearly $(p<.05)$ (Table 2$)$.

When analysing the data of both boys and girls without splitting them into groups of those who attended classes and those who did not, it was found that the optimism of middle school age boys was higher in physical education classes compared to the optimism of girls of the same age $(p<.05)$ (Table 3).

\section{DISCUSSION}

The results of this research have confirmed that there is a connection between optimism and the attendance of physical education classes, as well as higher physical activity in physical education classes. The results of this research comply with the conclusions of similar studies carried out by other authors, who discovered a positive correlation between physical activity and optimism (Hamid, 1990; Herero \& Extremera, 2010; Kavussanu \& McAuley, 1995). The fact that students start to think more optimistically when their physical activity increases mostly complied with the research data of Kavussanu and McAuley (1995).

The hypothesis that the optimism of boys is higher than the optimism of girls in physical education classes has been proven, as it was found that the optimism of middle school age boys was expressed more clearly in physical education classes compared to the optimism of girls of the same age ( $p$
$<.05)$. Similar results were obtained when studying the effect of educational consultations provided for older students during physical education classes (Rakauskienè \& Kardelienè, 2010): it was found that the emotions of boys are more positive, whereas the emotions of girls are more unbalanced. Based on the research results of Malinauskas and Malinauskienè (2007) who studied boys and girls engaged in sports activities, it was found that the emotions of boys engaged in sports activities were more positive $(p<.05)$ compared to girls of the same age also engaged in sports activities.

Our research data was different than the data obtained by Malinauskas and Klizas (2009), based on which a statistically significant difference was found between boys and girls according to their emotional comfort level in physical education classes: the emotions of girls in physical education classes were more positive, and they felt better $(p<.05)$.

Studies carried out both in foreign countries and in Lithuania suggest that regular physical activity among teenagers (boys and girls) is positively related to positive emotions (optimism) and lack of emotional problems (Malinauskas \& Klizas, 2009; Penedo \& Dahn, 2005; Rakauskiené \& Kardelienè, 2010; Sagatun, Søgaard, Bjertness, Selmer, \& Heyerdahl, 2007; Tao et al., 2007).

Teenagers who participate in sports experience fewer emotional (Desha, Ziviani, Nicholson, Martin, \& Darnell, 2007; Donaldson \& Ronan, 2006) and behavioural problems (Donaldson \& Ronan, 2006). According to the data of similar studies (Malinauskas \& Malinauskienè, 2007; 
Vojcik \& Brtkova, 2002), students (boys and girls) who do not avoid physical self-development are able to better control their emotions.

We agree to the position of researchers that if positive self-esteem of a middle school age student decreases, then the efforts of such a student in physical education classes or during physical exercises lose their value. Thus, positive selfesteem and self-image must be compatible with each other; otherwise the individual experiences regression (Ussher, Owen, Cook, \& Whincup, 2007). When failing to find a pillar of social support for self-confidence, positive self-esteem and optimism based on the respect of other people or the respect of a physical education teacher, then there is an increase in anxiety and the development of a depressive state occurs (opposite to optimism), which leads to behavioural changes and deterioration of performance resulting in low self-esteem (Кон, 2003). This also creates communication difficulties and other psychological consequences (adaptive aggression), as well as decreases the level of psychosocial adaptation (Кон, 2003). The refinement of needs for positive self-esteem leads to negative strategies, mechanisms and tactical actions for adaptation: rationalization, tendency for self-deception and lying, and this impedes student self-confidence and anxiety control in physical education classes (Klizas, 2009). Therefore, the development of optimism and self-esteem in physical education classes or during physical exercises is one of the measures of adaptation. This determines the student's interests, goals and wishes, serves as a source for appropriate development activities and invokes the remaining priority needs of the student. And since the orientation of middle school age students on active physical activities is strong, the general self-esteem of a student as well as the selfesteem of students in physical education classes is very important as it affects the student's level of psychosocial adaptation (Klizas, 2009).

To sum up, it can be stated that the physical activity of middle school age students is significantly correlated with positive emotions (optimism) and lack of emotional problems. However, a more detailed and more comprehensive research in this field is the object of further scientific studies since there is still a lack of studies that analyse the correlation between physical activity and positive emotions (optimism) in teenagers (Goldfield et al., 2011).

\section{CONCLUSIONS}

When evaluating optimism expression in physical education classes, it was found that middle school age students who attended physical education classes were more optimistic. When analysing the data of boys and girls separately, it was revealed that both boys and girls who attended physical education classes tended to feel more optimistic.

It was found that the optimism of middle school age boys was higher in physical education classes $(p<.05)$ comparing them to girls of the same age.

\section{REFERENCES}

Auweelle, Y. V., Bakker, F., Biddle, S., Durand, M., \& Seiler, R. (1999). Psychology for physical educators. Champaign, IL: Human Kinetics.

Barkauskaite, M. (2000). Paaugliu tarpusavio santykiu sociopedagogine dinamika (Habilitacinis darbas). Vilnius: VPU.

Bulotaite, L. (1995). Apie moksleivių savęs vertinimą. Vilnius: Simfonija.

Blauzdys, V., \& Šinkūnienè, D. (2005). Mokiniu papildomojo fizinio ugdymo plètra mokykloje. Vilnius: VPU.

Chang, E. C., \& Sanna, L. J. (2001). Optimism, pessimism, and positive and negative affectivity in middle-aged adults: A test of a Cognitive-Affective Model of Psychological Adjustment. Psychology and Aging, 16(3), 524-531.
Dember, W. N., Martin, S. H., Hummer, M. K., Howe, S. R., \& Melton, R. S. (1989). The measurement of optimism and pessimism. Current Psychological Research and Reviews, 8, 109-119.

Desha, L. N., Ziviani, J. M., Nicholson, J. M., Martin, G., \& Darnell, R. E. (2007). Physical activity and depressive symptoms in American adolescents. Journal of Sport \& Exercise Psychology, 29(4), 534-543.

Donaldson, S. J., \& Ronan, K. R. (2006). The effects of sports participation on young adolescents' emotional well-being. Adolescence, 41(162), 369-389.

Goldberg, A. D., \& Chandler, T. (1995). Sports counseling: Enhancing the development of the high school student athlete. Journal of Counseling \& Development, 74, 39-45. 
Goldfield, G. S., Henderson, K., Buchholz, A., Obeid, N., Nguyen, N., \& Flament, M. F. (2011). Physical activity and psychological adjustment in adolescents. Journal of Physical Activity and Health, 8, 157-163.

Hamid, P. N. (1990). Optimism and the reporting of flu episodes. Social Behavior and Personality, 18, 225-234.

Herero, V. G., \& Extremera, N. (2010). Daily life activities as mediators of the relationship between personality variables and subjective well-being among older adults. Personality and Individual Differences, 49, 124-129.

Himberg, C., Hutchinson, G., \& Roussell, J. (2003). Teaching secondary physical education: Preparing adolescents to be active for life. Champaign, IL: Human Kinetics.

Horn, T. S. (2004). Developmental perspectives on selfperceptions in children and adolescents. In M. R. Weiss (Ed.), Developmental sport and exercise psychology: A lifespan perspective (pp.101-144). Morgantown, WV: Fitness Information Technology.

Kavussanu, M., \& McAuley, E. (1995). Exercise and optimism: Are highly active individuals more optimistic? Journal of Sport and Exercise Psychology, 17(3), 246-258.

Kendall, F. (2001). Ypatingi tèvai - ypatingi vaikai. Vilnius: Andrena.

Keinys, S. (2003). Dabartinès lietuviu kalbos žodynas. Vilnius: Lietuvių kalbos instituto leidykla.

Klizas, Š. (2009). Viduriniojo mokyklinio amžiaus moksleiviu psichosocialine adaptacija ir jos stiprinimas per kūno kultūros pamokas (Daktaro disertacija). Kaunas: LKKA.

Lintunen, T., Leskinen, E., Oinonen, M., Salinto, M., \& Rahkila, P. (1995). Change, reliability, andstability in self-perceptions in early adolescence - A four yearfollow-up study. International Journal of Behavioral Development, 18, 351-364.

Malinauskas, R., \& Klizas, Š. (2009). Vidurinio mokyklinio amžiaus moksleivių psichosocialinė adaptacija per kūno kultūros pamokas. Jaunuju mokslininku darbai, 1(22), 114-117.

Malinauskas, R., \& Malinauskienè, V. (2007). Sportuojančių jaunuolių psichikos sveikata ir vidine darna. Sveikatos mokslai, 3(50), 936-938.

Marsh, H. W. (1989). Age and sex effects in multiple dimensions of self-concept: Preadolescence to early adulthood. Journal of Educational Psychology, 81, 417-430.

Masiulis, N. (2006). Fizinio aktyvumo poveikis stresui, nerimui ir depresijai mažinti. Šiuolaikinių technologiju analizè. Fizinis aktyvumas ir sveikata. Kaunas: LKKA.

Navaitis, G. (2001). Psichologinè parama paaugliui. Vilnius: Kronta.

Ostasevičienè, V. (2001). Neigaliu paaugliu dorybiu ugdymas taikomosios kūno kultūros užsiemimuose (Daktaro disertacija). Kaunas: LKKA.
Palujanskienè, A. (2003). Savęs vertinimo ir savijautos sąsajos ugdymo procese. Ugdymas. Kūno kultūra. Sportas, 4, 41-45.

Penedo, F. J., \& Dahn, J. R. (2005). Exercise and wellbeing: A review of mental and physical health benefits associated with physical activity. Current Opinion in Psychiatry, 18, 189-193.

Peterson, Ch., \& Steen, T. A. (2005). Optimistic Explanatory Style. Handbook of positive psychology. Oxford: Oxford University Press.

Petrauskienè,A., \& Matulevičiūtè, D. (2007). Abiturientų mokymosi krūvio ir savijautos sąsajos. Medicina, 43(4), 323-337.

Pivorienė, J., \& Jurkonytė, R. (2008). Moksleivių smurtas prieš pedagogus mokyklose. Socialinis darbas, 7(2), 76-82.

Poderys, J. (2000). Asmens sveikatos ugdymas. Kaunas: LKKA.

Rakauskienė, V., \& Kardelienė, L. (2010). Paaugliu elgesio ir emocijų pokyčiai, taikant trumpalaiki konsultavimą. Jaunujų mokslininku darbai, 1(26), 175179.

Rosenberg, M. (1985). Society and the adolescent selfimage. New York: Princeton University Press.

Sagatun, A., Søgaard, A. J., Bjertness, E., Selmer, R., \& Heyerdahl, S. (2007). The association between weekly hours of physical activity and mental health: A threeyear follow-up study of 15-16-year-old students in the city of Oslo, Norway. BMC Public Health, 7, 155-164. doi:10.1186/1471-2458-7-155

Scheier, M. F., \& Carver, C. S. (1992). Effects of optimism on psychological and physical wellbeing: Theoretical overview and empirical update. Cognitive Therapy and Research, 16, 201-228.

Šukys, S. (2001). Sportiné veikla kaip paaugliu vertybiniu orientaciju, asmenybès savybiu ir socialinio elgesio formavimosi veiksnys (Daktaro disertacija). Kaunas: LKKA.

Tao, F. B., Xu, M. L., Kim, S. D., Sun, Y., Su, P. Y., \& Huang, K. (2007). Physical activity might not be the protective factor for health risk behaviours and psychopathological symptoms in adolescents. Journal of Paediatrics and Child Health, 43(11), 762-767. doi: 10.1111/j.1440-1754.2007.01217.x

Thayer, R. E. (1987). Problem perception, optimism, and related states as a function of time of day (diumal rhythm) and moderate exercise: Two arousal systems in interaction. Motivation and Emotion, 11, 19-36.

Treben, M. (2006). Kasdienis stresas. Vilnius: Algarvè. Ussher, M. H., Owen, C. G., Cook, D. G., \& Whincup, P. H. (2007). The relationship between physical activity, sedentary behaviour and psychological wellbeing among adolescents. Social Psychiatry and Psychiatric Epidemiology, 42, 851-856. doi: 10.1007/ s00127-007-0232-x 
Vojcik, M., \& Brtkova, M. (2002). Longitudinal observation of the influence of yoga exercises and autotraining in training of young basketball players man. TVS Telesna Vychova \& Sport, 12(2), 15-18.

Weiss, M. R., \& Amorose, J. A. (2005). Children's self-perceptions in the physical domain: Between - and within-age variability in level, accuracy, and sources of perceived competence. Journal of Sport \& Exercise Psychology, 227(2), 226-244.

Zaborskis, A. (2001). Moksleiviu psichikos sveikata. Nacionalinis sveikatos tarybos pranešimas. Vilnius: Baltijos kopija.

Žemaitis, V. (1995). Dorovinis savęs vertinimas. Vilnius: Ethos.
Кон, И. С. (2003). Психология самосознания. Самара: Бахрах.

Милякова, Е. (2006). Психосоциальная адаптация личности девочки-подростка в системе адекватнного потребностно-мотивационного содержания физической культуры (Дисертационная работа канд. пед. Наук). Кишинёв: НИФВСРМ.

Немов, Р. С. (2001). Психология. Москва: ВЛАДОС.

Столяров, В. И. (1998). Актуальные провлемы теории и практики олимпиисково щброзования детеи и молодежы. Физическая Культура: Воспитарие, Образование, Тренировка, 4, 13-19. 